\title{
Effects of Aspartame on Maternal-Fetal and Placental Weights, Length of Umbilical Cord and Fetal Liver: A Kariometric Experimental Study
}

\author{
Efectos del Aspartame sobre el Peso Materno-Fetal y Placentario, Largo del Cordón Umbilical e \\ Hígado Fetal: Un Estudio Cariométrico Experimental
}

"Gabriela Soares Portela; ** Reinaldo Azoubel \& **Fernando Batigália

PORTELA, G. S.; AZOUBEL, R. \& BATIGÁLIA, F. Effects of aspartame on maternal-fetal and placental weights, length of umbilical cord and fetal liver: A Kariometric experimental study. Int. J. Morphol., 25(3):549-554, 2007.

SUMMARY: Aspartame is a synthetic sweetener consumed by more than half the adult population in 75 countries. Their metabolites can be toxic, principally to the liver and retina, and there are few studies on the use of aspartame in gestation.

Twenty pregnant rats were weighed and allocated randomly ( $\mathrm{n}=5$ per group) to receive $14 \mathrm{mg} / \mathrm{kg}$ aspartame or water by oralgastric drip. Treated T1: aspartame diluted in water at room temperature; Treated T2: aspartame diluted in water heated to $40^{\circ} \mathrm{C}$; control $\mathrm{C} 1$ : water at room temperature; and control C2: water heated to $40^{\circ} \mathrm{C}$. Placentas were weighed, umbilical cords measured and 1000 nuclei of fetal hepatocytes ( 250 from each group) were analyzed morphometrically utilizing the technique of kariometry, with application of the Mann-Whitney U-Test.

There were reductions in mean placental and maternal-fetal weights, in umbilical-cord length, and the majority of kariometric parameters of the hepatocytes in the group treated with aspartame diluted in distilled water at room temperature. Reduction of placental and maternal-fetal weights occurred, shortening of the umbilical cord, and decrease in kariometric parameters in fetal hepatocyte nuclei after administration of aspartame diluted in distilled water at $40^{\circ} \mathrm{C}$ temperature. The use of aspartame during gestation can be prejudicial to the fetus.

KEY WORDS: Aspartam; Fetus; Gestation; Liver; Kariometry.

\section{INTRODUCTION}

Aspartame (NL-alpha-Aspartyl-L-phenylalanine 1methyl ester) (Araújo et al., 1990) is a synthetic sweetener of low caloric value formed from the union of two aminoacids, aspartic acid and phenylalanine, with sweetening power 180 to 200 times greater than that of sacarose. It is consumed by half the adult population, in 75 countries, in the form of approximately 6000 products, such as soft drinks, chewing gum, fruit juices, gelatins and jellies (Grenby, 1991; Sanyudes, 1990).

Aspartame is metabolized in the gastrointestinal tract in aspartic acid, methanol and phenylalanine (Camfield et al., 1992), being that $10 \%$ of this metabolism results in methanol, which is oxidated in formaldehyde and formate in many tissues. Formic acid is considered the principal metabolite responsible for deleterious effects of acute intoxication by methanol in humans and animals (Butchko et al., 2002), able to cause blindness and loss of hepatic function since the liver and retina concentrate the greatest quantity of bioproducts of aspartame during intoxications (Trocho et al., 1988). Other symptoms may include allergic reactions in up to $20 \%$ of cases (urticaria, respiratory symptoms and edema of the lips, tongue, throat or salivary glands) or convulsive crises (Roberts et al.; Trocho et al.).

\footnotetext{
* Secretaria Municipal de Saúde de São José do Rio Preto - SP. Av. Romeu Strazzi, 199 Vila Sinibaldi - S J do Rio Preto - SP - Brasil.

** Faculdade de Medicina de São José do Rio Preto - SP. Av. Brigadeiro Faria Lima, 5416 São Manoel - S J Rio Preto - SP - Brasil.
} 
Since the prevalence of acute intoxication by aspartame tends to be low, there has been great acceptance of the product as a potent hypocaloric and trustworthy substitute of sugar (Butchko et al.). Considering the scarcity of literature in relation to the use of aspartame during gestation as well as its analysis at elevated temperatures, the objective of the present study was to evaluate experimentally, by means of kariometry, possible alterations in maternal-fetal body weight, placental weight, length of the umbilical cord and in nuclei of fetal hepatocytes, after administration of aspartame diluted at room temperature or heated to $40^{\circ} \mathrm{C}$.

\section{MATERIAL AND METHOD}

After ethical approval, twenty virgin rats were utilized (Rattus Norvergicus albinus, Wistar variety) (Kalter, 1974), weighing between 213 and $272 \mathrm{~g}$, and conditioned at night in communal cages, at the proportion of four females per one male. On the $9^{\text {th }}, 10^{\text {th }}$ and $11^{\text {th }}$ days of pregnancy (detected by vaginal smear), they were randomly placed into four experimental groups, with receipt of $14 \mathrm{mg} / \mathrm{kg}$ of aspartame by gavage. Treated group T1: 5 rats using aspartame diluted in water at room temperature; treated group $\mathrm{T} 2: 5$ rats using aspartame diluted in water heated to $40^{\circ} \mathrm{C}$; control group $\mathrm{C} 1$ : 5 rats administered water at room temperature, and control group C2: 5 rats using water heated to $40^{\circ} \mathrm{C}$.

On the $20^{\text {th }}$ day, all the rats were sacrificed by inhalation of sulfuric ether with extraction of fetuses, immediately immersed in a solution of Alfac for 24 hours. All fetuses were weighed on a precision balance and conserved in alcohol $80 \%$ for extraction of their respective livers, which were dehydrated, cleared and enclosed in paraffin in microtome section ( $6 \mu \mathrm{m}$ thickness $45 \mu \mathrm{m}$ space between cuts) and coloration by hematoxylin-eosin.

The kariometric technique was utilized for morphometric study (Harkema, 1997), with random selection of five fetuses from each group. The cuts were focalized and analyzed under light microscope (H 500 hund Wetzlar @ ) with the objective of immersion (augmented 100 times) and clear chamber (Leitzwetzlar - Germany $\left.{ }^{\circledR}\right)$. Nuclei of hepatocytes were projected onto paper with final augmentation of 1240 times. In the nuclear images obtained (50 images for each animal) outlined with a black number two pencil, were measured major (D) and minor (d) axes with millimeter ruler.

There were analyzed, in total, 1000 hepatocyte nuclei (250 for each group) utilizing the following morphometric parameters (Sala et al., 1994): major diameter, minor diameter, mean diameter, ratio between major and minor diameter, perimeter, volume, area, volume-to-area ratio, coefficient of form, index of contour and eccentricity. Diameters and perimeters were measured in micrometers $(\mu \mathrm{m})$, volumes in cubic micrometers $\left(\mu \mathrm{m}^{3}\right)$ and areas in square micrometers $\left(\mu^{2}\right)$. For mathematical calculations of morphometric studies, a computer program in Advanced Basic language was utilized. The non-parametric Mann-Whitney U-test was used for statistical analysis of data (Conover, 1999; Siegel, 1975) with values considered statiscally significant for $U \leq 4$, and adoption of alpha error of $5 \%$.

\section{RESULTS}

\section{Maternal-fetal and placental weights and measurement of the umbilical cord.}

There was a statistically significant reduction of arithmetic means of final body weights and mean of differences between initial weight and final weight, in the group treated with aspartame diluted in distilled water at room temperature, in relation to the control group (Table I). As to arithmetic means of body weights, a significant reduction occurred only for the mean difference between initial and final weights in the group treated with aspartame diluted in distilled water heated to $40^{\circ}$ C, compared with the control group (Table I).

With regard to arithmetic means of body weights and placental weights, there was a statistically significant reduction for the treated groups (in both aspartame diluted in distilled water at room temperature and in water heated to $40^{\circ} \mathrm{C}$ ) relative to the control group (Table II). There was also a reduction in mean measurements of umbilical cords only in the group treated with aspartame diluted in distilled water at room temperature (Table II).

\section{Morphometric results (kariometry).}

A statistically significant reduction was demonstrated for the major, minor and mean diameters; for volume, area, perimeter, volume-to-area ratio and index of contour (Table III) of hepatocyte nuclei in fetuses of rats treated with aspartame diluted in distilled water at room temperature, in relation to the control group.

There was no statistical difference between treated and control group for D/d ratio, eccentricity and coefficient of form in hepatocyte nuclei of rat fetuses treated with aspartame diluted in distilled water at room temperature (Table III). For the group treated with aspartame diluted in distilled water heated to $40^{\circ} \mathrm{C}$, there was no statistical difference for any kariometric parameter relative to the control group (Table III). 
PORTELA, G. S.; AZOUBEL, R. \& BATIGÁLIA, F. Effects of aspartame on maternal-fetal and placental weights, length of umbilical cord and fetal liver: A Kariometric experimental study. Int. J. Morphol., 25(3):549-554, 2007.

Table I. Mean values of initial corporal weight, final corporal weight, difference between final and initial corporal weight and number of fetuses in control groups (C1 and C2) and treated groups (T1 and T2). Mann-Whitney test (U) and p-value (p).

\begin{tabular}{|c|c|c|c|c|c|c|c|c|}
\hline \multirow[b]{2}{*}{ Parameter } & \multicolumn{4}{|c|}{$\begin{array}{l}\text { Aspartame diluted in distilled water at room } \\
\text { temperature }\end{array}$} & \multicolumn{4}{|c|}{$\begin{array}{l}\text { Aspartame diluted in distilled water heated to } \\
\qquad 40^{\circ} \mathrm{C}\end{array}$} \\
\hline & $C 1$ & $T 1$ & $U$ & $p[U]$ & $C 2$ & $T 2$ & $U$ & $p[U]$ \\
\hline Initial weight (g) & 247.8 & 229.8 & 4 & $0.048^{*}$ & 240.7 & 245.5 & 9 & 0.274 \\
\hline Final weight (g) & 333.2 & 286.4 & 0 & $0.004^{*}$ & 346.1 & 338.9 & 11 & 0.421 \\
\hline $\begin{array}{l}\text { Difference between final and } \\
\text { initial corporal weight }(\mathrm{g})\end{array}$ & 89.2 & 56.6 & 0 & $0.004 *$ & 107.4 & 93.4 & 0 & $0.004 *$ \\
\hline Number of fetuses & 09 & 10 & 7 & 0.155 & 11 & 10.4 & 7 & 0.155 \\
\hline
\end{tabular}

Table II. Mean values of corporal weight, placental weight and umbilical cord length in control groups (C1 and C2) and treated groups (T1 and T2). Mann-Whitney test (U) and p-value (p).

\begin{tabular}{|c|c|c|c|c|c|c|c|c|}
\hline \multirow[b]{2}{*}{ Parameter } & \multicolumn{4}{|c|}{$\begin{array}{l}\text { Aspartame diluted in distilled water at room } \\
\text { temperature }\end{array}$} & \multicolumn{4}{|c|}{$\begin{array}{l}\text { Aspartame diluted in distilled water heated to } \\
\qquad 40^{\circ} \mathrm{C}\end{array}$} \\
\hline & $\mathrm{C} 1$ & $\mathrm{~T} 1$ & $U$ & $\mathrm{p}[U]$ & $\mathrm{C} 2$ & $\mathrm{~T} 2$ & $U$ & $\mathrm{p}[U]$ \\
\hline Corporal weight (g) & 2.503 & 1.557 & 1 & $0.008 *$ & 2.685 & 1.720 & 0 & $0.004 *$ \\
\hline Placental weight (g) & 0.398 & 0.247 & 2 & $0.016^{*}$ & 0.339 & 0.263 & 3 & $0.028 *$ \\
\hline Umbilical cord length (cm) & 1.8 & 1.5 & 2 & $0.016^{*}$ & 1.8 & 1.7 & 6 & 0.111 \\
\hline
\end{tabular}

* Significance difference $\mathrm{p}=0,05$

Table III. Mean values of kariometric parameters of hepatocyte nuclei in control groups (C1 and C2) and treated groups (T1 and T2). Mann-Whitney test (U) and p-value (p).

\begin{tabular}{|c|c|c|c|c|c|c|c|c|}
\hline \multirow[b]{2}{*}{ Parameter } & \multicolumn{4}{|c|}{$\begin{array}{l}\text { Aspartame diluted in distilled water at room } \\
\text { temperature }\end{array}$} & \multicolumn{4}{|c|}{$\begin{array}{l}\text { Aspartame diluted in distilled water heated to } \\
\qquad 40^{\circ} \mathrm{C}\end{array}$} \\
\hline & $\mathrm{C} 1$ & T1 & $U$ & $\mathrm{p}[U]$ & $\mathrm{C} 2$ & $\mathrm{~T} 2$ & $U$ & $\mathrm{p}[U]$ \\
\hline Greatest nucle ar diameter & 1.49 & 1.30 & 0 & $0.004 *$ & 1.44 & 1.44 & 11 & 0.421 \\
\hline Smallest nucle ar diameter & 1.11 & 0.94 & 0 & $0.004 *$ & 1.03 & 1.03 & 10 & 0.345 \\
\hline Mean diameter & 1.28 & 1.11 & 0 & $0.004 *$ & 1.22 & 1.21 & 11 & 0.421 \\
\hline Greatest/smallest diameter ratio & 1.36 & 1.39 & 6 & 0.111 & 1.40 & 1.41 & 12 & 0.500 \\
\hline Nuclear volume & 1.15 & 0.74 & 0 & $0.004 *$ & 0.96 & 0.97 & 11 & 0.421 \\
\hline Nucle ar area & 1.31 & 0.97 & 0 & $0.004 *$ & 1.18 & 1.17 & 10 & 0.345 \\
\hline Nucle ar perimeter & 4.11 & 3.55 & 0 & $0.004 *$ & 3.92 & 3.92 & 11 & 0.421 \\
\hline Volume/area ratio & 0.85 & 0.73 & 0 & $0.004 *$ & 0.81 & 0.81 & 8 & 0.210 \\
\hline Eccentricity & 0.64 & 0.66 & 7 & 0.155 & 0.68 & 0.68 & 11 & 0.421 \\
\hline Nucle ar shape coefficient & 0.95 & 0.95 & 8 & 0.210 & 0.95 & 0.95 & 10 & 0.345 \\
\hline Contour index & 3.61 & 3.62 & 3 & $0.028 *$ & 3.62 & 3.63 & 10 & 0.345 \\
\hline
\end{tabular}

* Significance difference $\mathrm{p}=0,05$ 


\section{DISCUSSION}

Epidemiological studies of alimentary additives are important in toxicological risk evaluation for humans, though these are difficult to accomplish since the exposure cannot be evaluated precisely and the analysis of risk depends, principally, on toxicological laboratory studies (Sasaki et al., 2002). Cumulative effects derived from chronic administration of aspartame suggest that its ingestion can result in progressive accumulation of formaldehyde products, which could explain the chronic effects that aspartame consumption can induce in sensitive tissues, such as in the brain and liver (Trocho et al.).

In rats, gestation lasts twenty-one days and embryogenesis is initiated on the eighth day, and is prolonged until the fourteenth day (Rugh, 1968). During this phase exposure to a teratogenic agent can provoke specifically malformations of diverse organs in development. In this study aspartame was administered on the $9^{\text {th }}, 10^{\text {th }}$ and $11^{\text {th }}$ days of gestation, which coincided with the teratogenic period (Rugh). The results presented suggested that aspartame caused damage to the rat fetuses.

One of the deleterious effects of aspartame observed in this study was demonstrated by diminution of fetal weight. The mean body weight of fetuses belonging to the group treated with aspartame diluted in distilled water at room temperature, was observed to be significantly diminished, in relation to the control group fetal weight. There was also a statistically significant difference between initial and final body weights in rats treated with aspartame diluted in distilled water heated to $40^{\circ} \mathrm{C}$, compared to that of the control group, which is suggestive of weight reduction caused by the use of aspartame (Astrup et al., 2002; Kanders et al., 1988, 1992; Toledo \& Ioshi, 1995; Tordoff \& Alleva, 1990).

The length of the umbilical cord has been considered a trustworthy indicator of fetal movement by being influenced by the frequency of fetal movement and by space available in the uterine cavity. It is known that diminution of space or blockage of fetal movement cause diminution of the extension and length of the umbilical cord (Miller et al., 1981; Moessinger et al., 1982; Yyengar \& Rapp, 2001). In this study, placentas from animals of the two treated groups were significantly diminished in relation to the control group, which may suggest reduction in space available in the uterine cavity as consequent shortening of the umbilical cord.

Kariometric studies permit the obtainment of data of both physiological and pathological interest, effect quantitative correlations between normal or altered structure and function and aid in diagnosis of cellular alterations (Chalkley et al. 1943,1949; Sala et al., 1980). This kariometric study of hepatocyte nuclei suggest maternal hepatic toxicity from administration of aspartame diluted in distilled water at room temperature, which provokes question as to maturation and degree of hepatic recuperation with the use of aspartame during gestation, necessitating future investigations.

Products with aspartame contain on packaging a warning to carriers of phenylketonuria about the presence of phenylalanine (Grenby). It would be of interest for such products to carry advisories for pregnant women regarding the risk of ingesting aspartame, in the same way it happens with medicaments. This study suggests that consumption of products containing aspartame be avoided during the gestational period.

PORTELA, G. S.; AZOUBEL, R. \& BATIGÁLIA, F. Efectos del aspartame sobre los pesos materno-fetal y placentario, largo del cordón umbilical e hígado fetal: Un estudio cariométrico experimental. Int. J. Morphol., 25(3):545-548, 2007.

RESUMEN: El aspartame es un endulzante sintético consumido por más de la mitad de la población adulta, en 75 países. Sus metabolitos pueden ser tóxicos, principalmente en el hígado y retina y hay algunos estudios sobre el aspartame en el embarazo.

Veinte ratas preñadas fueron pesadas y distribuidas aleatoriamente ( $\mathrm{n}=5$ por grupo) y recibieron $14 \mathrm{mg} / \mathrm{Kg}$ de aspartame o agua por vía oral- gástrica. Tratamiento 1: aspartame diluido en agua a temperatura ambiente; Tratamiento T2: aspartame diluido en agua tibia a $40{ }^{\circ} \mathrm{C}$; control $\mathrm{C} 1$ : agua a temperatura ambiente, y control C2: agua tibia a $40^{\circ} \mathrm{C}$. Las placentas fueron pesadas, el cordón umbilical medido y 1000 núcleos de hepatocitos fetales (250 de cada grupo) se analizaron morfométricamente utilizando la técnica de cariometría con aplicación del Test U de Mann-Whitney U-Test.

En el grupo tratado con aspartame diluido en agua a temperatura ambiente, hubo reducción en los pesos promedios de la placenta y materno-fetal, largo del cordón umbilical y en la mayoría de los parámetros cariométricos de los hepatocitos. Lo mismo ocurrió en el grupo tratado con aspartame diluido en agua a $40{ }^{\circ} \mathrm{C}$. El uso del aspartame durante las gestación puede ser perjudicial para el feto.

PALABRAS CLAVE: Aspartame; Feto; Gestación; Hígado; Cariometría. 
PORTELA, G. S.; AZOUBEL, R. \& BATIGÁLIA, F. Effects of aspartame on maternal-fetal and placental weights, length of umbilical cord and fetal liver: A Kariometric experimental study. Int. J. Morphol., 25(3):549-554, 2007.

\section{REFERENCES}

Araújo, C. L. C.; Vanzellotti, I. R.; Lemos, J. I. \& Azevedo, M. F. Stedman's medical dictionary. 25. ed. Baltimore, Williams \& Wilkins, 1990. p. 117.

Astrup, A.; Raben, A.; Vasilaras, T. H. \& Moller, A.C. Sucrose in soft drinks is fattening: A randomized 10 week study in overweight subjects. Am. J. Clin. Nutr., 75: 405S, 2002.

Butchko, H. H.; Stargel, W. W.; Comer, C. P.; Mayhew, D. A.; Benninger, C.; Blackburn, G. L.; Sonnevile, L. M. J.; Geha, R. S.; Hertelendy, Z.; Koestner, A.; Leon, A. S.; Liepa, G. U.; McMartin, K. E. \& Mendenhall, C. L. Aspartame: Review of safety. Regul. Toxicol. Pharmacol., 35 (2 Pt 2):S1-93, 2002.

Camfield, P. R.; Camfield, C. S.; Dooley, J. M.; Gordon, K.; Jollymore, S. \& Weaver, D. F. Aspartame exacerbates EEG spike-wave discharge in children with generalized absence epilepsy: a double-bind controlled study. Neurology, 42:1000-3, 1992.

Chalkley, H.W. Method for the quantitative morphologic analysis of tissues. J. Natl. Cancer Inst., 4:47-53, 1943.

Chalkley, H. W.; Corneld, J. \& Park, H. A method for estimating volume-surface ratios. Science, 23(110):2957, 1949.

Conover, W. J. Practical nonparametric statistics. $3^{\text {th }}$. ed. New York, John Willey \& Sons, 1999.

Grenby, T.H. Update on low calories sweeteners to benefit dental health. Int. Dent. J., 41(4):217-24, 1991.

Harkema, J. R. Morphometric methods for studying airway cell density/proliferation. American Thoracic Society. American Lung Association. San Francisco (CA): Posgraduate Course 3; 1997.

Kalter, H. Choice of the number of sampling units in teratology. Teratology, 9(3):257-8, 1974.

Kanders, B. S. \& Blackburn, G.L. Reducing primary risk factors by therapeutic weight loss. In: Wadden, T.A.; Van Itallie, T.B., editors. The treatment of the seriously obese patient. New York, Guilford, 1992. pp. 213-30.

Kanders, B. S.; Lavin, P. T.; Kowalchuck, M. B.; Greenberg, I. \& Blackburn, G. L. An evaluation of the effect of aspartame on weight loss. Appetite, 11 Supl., 1:73-84, 1988.
Miller, M. E.; Higginibotton, M.; Smith, D.W. Short umbilical cord: its origin and relevance. Pediatrics Evanston, 67(5):616-21, 1981.

Moessinger, A. C.; Blanc, W. A.; Marone, P. A. \& Polsen, D.C. Umbilical cord length as an index of fetal activity: experimental study and clinical implications. Pediatric Research, 16(2):109-12, 1982.

Roberts, H. J. Aspartame as a cause of allergic reactions, including anaphylaxis [carta]. Arch. Intern. Med., 13: 156:1027, 1996.

Rugh, R. Organogeny. In: Rugh, R., editor. The mouse. Its reproduction and development. Columbia: Burgess Publishing Company, 1968. p.276.

Sala, M. A.; Komesu, M. C.; Lopes, P. A.; Maia Campos, G. Karyometric study of basal cell carcinoma. Braz. Dent. J., 5:11-4, 1994.

Sala, M. A.; Matheus, M.; Valeri, V. Estimation of the average diameter of human placental villi by a stereological method. Microsc Acta, 82:339-42, 1980.

Sanyudes, S. Alternative sweeteners. Can. Pharmaceutical J., 123:455-60, 1990.

Sasaki, Y. F.; Kawaguchi, S.; Kamaya, A.; Ohshita, M.; Kabasawa, K.; Iwama, K.; Taniguchi, K. \& Tsuda, $\mathrm{S}$. The comet assay 8 mouse organs: results with 39 currently used food additives. Mutation Research, 519:103-19, 2002.

Siegel, S. Apêndice K. Estatística não paramétrica para as ciências do comportamento. 1. ed. São Paulo, Mc Graw-Hill, 1975.

Stedman's medical dictionary. 25. ed. Baltimore, Williams \& Wilkins, 1990. p.117.

Toledo, M. C. \& Ioshi, S.H. Potential intake of intense sweeteners in Brazil. Food Addit. Contam., 12:799808, 1995.

Tordoff, M. G. \& Alleva, A.M. Effect of drinking soda sweetned with aspartame or high-fructose corn syrup on food intake and body weight. Am. J. Clin. Nutr., 51:963-9, 1990. 
PORTELA, G. S.; AZOUBEL, R. \& BATIGÁLIA, F. Effects of aspartame on maternal-fetal and placental weights, length of umbilical cord and fetal liver: A Kariometric experimental study. Int. J. Morphol., 25(2):549-554, 2007.

Trocho, C.; Pardo, R.; Rafecas, I.; Virgili, J.; Remesar, X.; Fernández-Lópes, J. A. \& Alemany, M. Formaldehyde derived from dietary aspartame binds to tissue components in vivo. Life Sciences, 63(5):337-49, 1988.

Yyengar, G.V. \& Rapp, A. Human placenta as a dual'biomaker for monitoring fetal and maternal environment with spacial reference to potentially toxic trace elements. Sci. Total Enviaron., 280 (Pt 3):221-38, 2001.
Correspondence to:

Prof. Dr. Reinaldo Azoubel

Faculdade de Medicina de São José do Rio Preto - SP.

Av. Brigadeiro Faria Lima, 5416

São Manoel - S J Rio Preto

SP - BRASIL

Received: 20-02-2007

Accepted: 23-05-2007 